\title{
TNF- $\alpha$ augments the expression of RhoA in the rat bronchus
}

\author{
Hiroyasu SAKAI ${ }^{1}$, Shinobu OTOGOTO ${ }^{1}$, Yoshihiko CHIBA $^{1}$, \\ Kazuho $\mathrm{ABE}^{1}$ and Miwa MISAWA ${ }^{1}$ \\ ${ }^{1}$ Department of Pharmacology, School of Pharmacy, Hoshi University, Tokyo, Japan
}

\begin{abstract}
While nonspecific airway hyperresponsiveness (AHR) is a central feature of allergic bronchial asthma, the mechanism underlying the developmont of AHR is not clearly understood. We have previously demonstrated in vitro hyperresponsiveness of bronchial smooth muscle to acetylcholine ( $\mathrm{ACh}$ ) in rats that were actively sensitized and repeatedly challenged with aerosolized antigen. It has also been demonstrated that the AChinduced, RhoA-mediated $\mathrm{Ca}^{2+}$ sensitization is markedly augmented concomitantly with an increased expression and activation of RhoA protein in the bronchial smooth muscle of the antigen-treated rats. In the present study, we have investigated whether TNF- $\alpha$, a proinflammatory cytokine which is involved in bronchial asthma, causes upregulation of RhoA mRNA and protein in the rat bronchus. Treatment of rat bronchial smooth muscle preparations with TNF- $\alpha(300 \mathrm{ng} / \mathrm{ml}$ for $24 \mathrm{hr})$ significantly shifted the concentrationresponse curve to ACh upwards, but did not alter the response to high $\mathrm{K}^{+}$, when compared to that of control tissues. Levels of RhoA mRNA and protein in the TNF- $\alpha$ treated bronchus were significantly greater than those in the control group. In conclusion, it is suggested that the augmentation of the ACh-induced contractile response evoked by TNF- $\alpha$ might be mediated by an upregulation of RhoA in rat bronchial smooth muscle.
\end{abstract} RhoA

Key words: TNF- $\alpha$, airway hyperresponsiveness, smooth muscle, acetylcholine,

\section{Introduction}

Bronchial asthma is a complex inflammatory disease of the lung which has had an increased incidence worldwide over the last two decades. Airway hyperresponsiveness (AHR) and inflammation leading to an increased airway resistance are characteristic features of asthma (Bousquet, 2000). The importance of AHR in the pathogenesis of asthma has been suggested by its correlation with the severity of this disease (Lotvall et al., 1998). Therefore, the underlying mechanisms of AHR need to be determined to assist with the treatment of asthma.

Correspondence to: Y. Chiba, Ph.D., Department of Pharmacology, School of Pharmacy, Hoshi University, 2-4-41 Ebara, Shinagawa-ku, Tokyo 142-8501, Japan.

Phone: +81-3-5498-5786 Fax: +81-3-5498-5787 e-mail: chiba@hoshi.ac.jp 
On the other hand, there is increasing evidence that tumor necrosis factor-alpha (TNF- $\alpha$ ), one of the proinflammatory cytokines produced by a variety of cells in the airways such as epithelial cells (Devakua et al., 1993; Ackerman et al., 1994), macrophages (Gosset et al., 1992), mast cells (Gordon et al., 1990; Bradding et al., 1994) and eosinophils (Costa et al., 1993; Finotto et al., 1994), is directly linked to airway inflammation and the hyperresponsiveness observed in asthma (Shah et al., 1995). The level of TNF- $\alpha$ is elevated in the sputa and bronchoalveolar lavage fluid (BALF) of patients with bronchial asthma (Taki et al., 1991; Broide et al., 1992). In mouse (Lucacs et al., 1995), guinea pig (Watson et al., 1993) and rat (Escott et al., 2000) models of lung inflammation, increased levels of TNF- $\alpha$ have been detected in the BALF of sensitized animals following challenge with an antigen. In addition, in vivo pretreatment of rat and human airways with aerosolized TNF- $\alpha$ produced an enhanced increase in airway resistance, similar to that observed in asthma, when challenged with endogenous agonists (Kips et al., 1992; Thomas et al., 1995). Pharmacological evidence has also pointed towards an important role of TNF- $\alpha$ in airway hyperresponsiveness. TNF- $\alpha$ receptor fusion protein, which can potently block the endogenous TNF- $\alpha$-mediated reaction, is effective in reducing both the enhanced airway reactivity and the infiltration of inflammatory cells into the airways in sensitized guinea pigs and Brown-Norway rats in vivo (Renzetti et al., 1996). Moreover, TNF- $\alpha$ potentiated the contractile response of the human bronchus to ACh (Sukkar et al., 2001). These observations suggest that TNF- $\alpha$ may be one of the primary components responsible for the bronchial smooth muscle hyperresponsiveness observed in asthma.

We have already demonstrated the occurrence of both in vivo and in vitro hyperresponsiveness in rats that were actively sensitized and repeatedly challenged with aerosolized antigen (Chiba et al., 1993; Chiba et al., 1995). We have also previously reported that the muscarinic receptor density of bronchial tissues in the AHR rat model following repeated antigen challenge was within normal levels (Chiba et al., 1995). Moreover, no significant difference in the ACh-induced increase in cytosolic $\mathrm{Ca}^{2+}$ concentration of the main bronchial smooth muscle was observed between control and AHR rats (Chiba et al., 1999a). These findings strongly suggest that the mechanisms responsible for the augmented AChinduced contraction of the main bronchial smooth muscle might exist within post-muscarinic receptor signaling which includes augmented $\mathrm{Ca}^{2+}$ sensitization. In a previous study, the level of RhoA, an important protein that mediates $\mathrm{Ca}^{2+}$ sensitization and $\mathrm{ACh}$-induced $\mathrm{Ca}^{2+}$ sensitization in bronchial preparations from rats that had been repeatedly antigen challenged, was significantly increased as compared with those of control rats (Otto et al., 1996). The $\mathrm{Ca}^{2+}$ sensitization was abolished by pretreatment with the C3 toxin, Rho inhibitor (Chiba et al., 1999b). It is therefore possible that the increased RhoA enhances $\mathrm{Ca}^{2+}$ sensitizing signal, resulting in augmentation of the ACh-induced contractile response in the AHR rats.

There is no evidence that TNF- $\alpha$ directly augments agonist-induced rat bronchial smooth muscle. In the present study, the effects of TNF- $\alpha$ treatment on the smooth muscle responsiveness of airways were investigated in association with changes in RhoA protein and mRNA levels in TNF- $\alpha$-treated rat bronchus to further investigate the mechanism involved in the development of AHR. 


\section{Materials and Methods}

\section{Animals}

Male Wistar rats (6 weeks of age, specific pathogen-free, 170-190 g, Charles River Japan, Inc) were housed for appropriate time intervals in the animal center of Hoshi University after delivery, in accordance with the guidelines approved by the Animal Care Committee of Hoshi University (Tokyo, Japan) for the care and use of laboratory animals. The animals were maintained at a constant temperature and humidity $\left(22 \pm 1^{\circ} \mathrm{C}, 55 \pm 10 \%\right)$, with a fixed 12-hr lightdark cycle and free access to food and water.

\section{Functional study}

The animals were killed by exsanguination from the abdominal aorta under anesthesia with chloral hydrate (400 mg/kg, i.p.). An approximately $4 \mathrm{~mm}$ length of the left main bronchus was isolated as described previously (Chiba et al., 1993). After treatment with TNF- $\alpha(300 \mathrm{ng} / \mathrm{ml})$ or its vehicle in Krebs-Henseleit solution with the following composition (mM); $\mathrm{NaCl} 118.0, \mathrm{KCl}$ 4.7, $\mathrm{CaCl}_{2} 2.5, \mathrm{MgSO}_{4} 1.2, \mathrm{NaHCO}_{3} 25.0, \mathrm{KH}_{2} \mathrm{PO}_{4} 1.2$ and glucose $10.0(\mathrm{pH} 7.4$ ) at room temperature for 1 or $24 \mathrm{hr}$, the resultant tissue ring preparations were then suspended in a 5 -ml organ bath at a resting tension of $1.0 \mathrm{~g}$. The isometric contraction of the circular smooth muscle was measured with a force-displacement transducer (TB-612T, Nihon Kohden, Japan). The organ bath contained modified Krebs-Henseleit solution. The buffer solution was maintained at $37^{\circ} \mathrm{C}$ and oxygenated with $95 \% \mathrm{O}_{2}-5 \% \mathrm{CO}_{2}$. During an equilibration period in the organ bath, the tissues were washed four times at 15-min intervals and equilibrated slowly to a baseline tension of $1.0 \mathrm{~g}$. Fifteen min after the last washing, higher concentrations of acetylcholine (ACh) were successively added after attainment of a plateau response to the previous concentration. After measurement of $\mathrm{ACh}$ responsiveness, the bronchial smooth muscle was also depolarized with isotonic high $\mathrm{K}^{+}$solution prepared by iso-osmotic replacement of $\mathrm{NaCl}$ by $\mathrm{KCl}$ in the presence of $10^{-6} \mathrm{M}$ atropine and $10^{-6} \mathrm{M}$ indomethacin.

\section{RT-PCR analysis}

Three, 6,15 or $18 \mathrm{hr}$ after incubation with TNF- $\alpha(300 \mathrm{ng} / \mathrm{ml})$, main and intrapulmonary bronchial tissues were quickly frozen with liquid nitrogen, and the tissue crushed using a Cryopress $^{\mathrm{TM}}$ (CP-100W; Niti-on, Co. Ltd., Japan: $15 \mathrm{sec} \times 3$ ). Total RNA was isolated from each frozen tissue sample using acid guanidium thiocyanate/phenol/chloroform extraction (Mullis $e t$ $a l .$, 1989) and stored at $-85^{\circ} \mathrm{C}$ until use.

cDNAs were prepared from the total RNA $(0.5 \mu \mathrm{g})$ by using a Takara RNA PCR Kit (Ver. 2.1; Takara, Tokyo, Japan) in a total volume of $20 \mu \mathrm{L}$ reaction buffer containing $10 \mathrm{mM}$ Tris- $\mathrm{HCl}$, $\mathrm{pH}$ 8.3, $50 \mathrm{mM} \mathrm{MgCl}, 1 \mathrm{mM}$ dNTP mixture, $1 \mathrm{U} / \mathrm{ml}$ RNase inhibitor, $2.5 \mu \mathrm{M}$ random 9-mers and $0.25 \mathrm{U} / \mathrm{ml}$ avian myeloblastosis virus reverse transcriptase. The reaction mixture was incubated for $10 \mathrm{~min}$ at $30^{\circ} \mathrm{C}$ followed by $60 \mathrm{~min}$ at $42^{\circ} \mathrm{C}$ to initiate the synthesis of the cDNAs. The reverse transcriptase was inactivated at $99^{\circ} \mathrm{C}$ for $5 \mathrm{~min}$. Then to the RT reaction mixture $(10 \mu \mathrm{L})$ was added $0.5 \mu \mathrm{L}$ of $0.1 \mathrm{mM}$ forward primer, $0.5 \mu \mathrm{L}$ of $0.1 \mathrm{mM}$ reverse primer, $4 \mu \mathrm{L}$ of $10 \mathrm{X}$ amplification buffer (100 mM Tris- $\mathrm{HCl}, \mathrm{pH} 8.3,0.5 \mathrm{M} \mathrm{KCl}), 3 \mu \mathrm{L}$ of $25 \mathrm{mM} \mathrm{MgCl}, 31.8 \mu \mathrm{L}$ 
of $\mathrm{H}_{2} \mathrm{O}$, and $0.25 \mu \mathrm{L}$ of $5 \mathrm{U} / \mathrm{ml}$ Taq polymerase. The PCR primers for rat rhoA were 5'GTGATTGTTGGTGATGGAGC-3' (sense) and 5'CTCGTGGCCATCTCAAAAAC-3' (antisense) (Yoshimura et al., 1997). The PCR primers for rat glyceraldehyde-3-phosphate dehydrogenase (GAPDH) were 5'-CCATCACTGCCACTCAGAAGAC-3' (sense) and 5'TACTCCTTGGAGGCCATGTAGG-3' (antisense), which were made from published sequences. The thermal cycle profile used in the present study was 1) denaturing for $30 \sec$ at $95^{\circ} \mathrm{C}, 2$ ) annealing primers for $30 \mathrm{sec}$ at $60^{\circ} \mathrm{C}$ and 3) extending the primers for $60 \mathrm{sec}$ at $72^{\circ} \mathrm{C}$. The PCR amplifications were performed for 25 cycles. A portion $(10 \mu \mathrm{L})$ of the PCR mixture was subjected to electrophoresis on a $2 \%$ agarose gel (E-Gel ${ }^{\mathrm{TM}}$; Invitrogen, $\mathrm{CA}$, USA) and visualized using a densitometer (Atto Densitograph; Atto Co., Tokyo, Japan). The ratios of the corresponding rhoA/GAPDH were calculated as indices of rhoA mRNA levels.

\section{Western blot analysis}

In the rhoA expression study, the samples were subjected to $15 \%$ SDS-polyacrylamide gel electrophoresis. Proteins were then electrophoretically transferred to PVDF membranes. After blocking, the membranes were then incubated with the primary antibodies. The primary antibodies used were rabbit anti-RhoA (1:2000 dilution; Santa Cruz Biotechnology, Inc) or mouse anti-GAPDH (glyceraldehyde-3-phosphate dehydrogenase) (1:3000 dilution; Chemicon). Then the membranes were incubated with horseradish peroxidase-conjugated goat anti-rabbit immunoglobulin (Ig) G (1:5000 dilution; Amersham) and goat anti-mouse IgG (1:5000 dilution; Amersham) and detected by an ECL System. The ratio of the corresponding RhoA/GAPDH in each lane was calculated as an index of the RhoA level. We used GAPDH as an internal control because this protein is also constitutively expressed in most tissues and is the most widely accepted internal control in the molecular biology literature.

\section{Statistical analyses}

All the data were expressed as the mean and S.E.M. Statistical significance of differences was determined by two way analysis of variance (ANOVA).

\section{Results}

\section{Functional study}

Figure 1 shows the effects of a 24-hr incubation with TNF- $\alpha$ on bronchial smooth muscle responsiveness. As compared with vehicle-incubated control preparations, the ACh responsiveness in TNF- $\alpha(300 \mathrm{ng} / \mathrm{ml})$-treated groups was significantly augmented (Fig. 1A): the Emax of TNF- $\alpha$-treated groups $(1.63 \pm 0.07 \mathrm{~g}$ tension, $\mathrm{p}<0.01)$ was significantly greater than that of the vehicle-incubated group $(1.13 \pm 0.10 \mathrm{~g})$. On the other hand, no significant difference in the response to isotonic high $\mathrm{K}^{+}(10,30$ and $60 \mathrm{mM})$ was observed between the groups (Fig. 1B).

\section{RT-PCR analysis}

Figure 2 shows the expression of rhoA and GAPDH mRNAs in rat bronchial preparations, as 

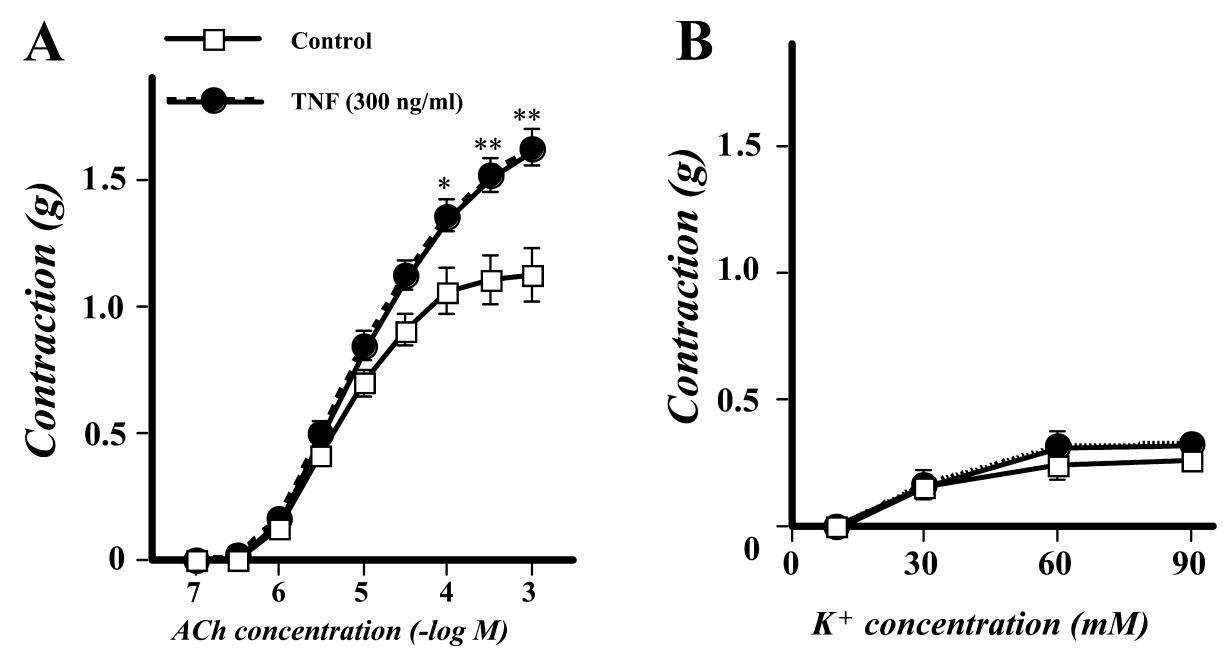

Fig. 1. Acetylcholine (ACh; $\mathrm{A})$ and high $\mathrm{K}^{+}(\mathrm{B})$ concentration-response curves in rat bronchial ring preparations following treatment with tumor necrosis factor- $\alpha$ (TNF- $\alpha$ ) (300 ng/ $\mathrm{ml}$ ) or its vehicle control (Control) for $24 \mathrm{hr}$. Each point represents the mean and S.E. from 5 experiments. In the TNF- $\alpha$-treated group, ACh responsiveness of the main bronchial smooth muscles was significantly $(\mathrm{p}<0.05$, by ANOVA; $300 \mathrm{ng} / \mathrm{ml}$ and $\mathrm{p}<0.01)$ augmented as compared to that of the vehicle control group. ${ }^{*}: \mathrm{p}<0.05$ and ${ }^{* *}: \mathrm{p}<0.01$ (TNF- $\alpha, 300 \mathrm{ng} / \mathrm{ml})$ vs. vehicle control.

determined by RT-PCR using total RNA. The PCR amplification was performed for 25 cycles and showed submaximal but distinct bands. The expected bands for rhoA (503 bp) and GAPDH (468 bp) were clearly detected in the rat bronchial tissue (data not shown). The band intensities for rhoA, but not GAPDH, were TNF- $\alpha$-treated time-dependently increased. In order to estimate the extent of expression of rhoA mRNA, the ratios of the band intensity of rhoA mRNA to that of GAPDH were calculated. The level of expression of rhoA mRNA was time-dependently increased in TNF- $\alpha$-treated bronchial tissue. The relative rhoA mRNA obtained from the TNF$\alpha$-treated (for $18 \mathrm{hr}$ ) bronchial tissue was significantly increased as compared to that from nontreated bronchial tissue, whereas the band intensity for GAPDH remained at the same level (data not shown).

\section{Western blot analysis}

In the present study, anti-RhoA antibody was used to detect RhoA protein in TNF- $\alpha$-and vehicle-treated bronchial preparations. Representative immunoblots for RhoA and GAPDH from TNF- $\alpha$-treated and its vehicle control preparations are shown in Fig. 3A. Immunoblotting with the antibody against RhoA showed a single $21 \mathrm{kD}$ band, indicating the existence of RhoA proteins in the rat bronchi. The ratios of corresponding RhoA/GAPDH were calculated and represented in Fig. 3B. The relative expression of RhoA protein in the TNF- $\alpha$-treated bronchial preparation was significantly increased as compared with that in the vehicle control preparation $(\mathrm{p}<0.05)$. 


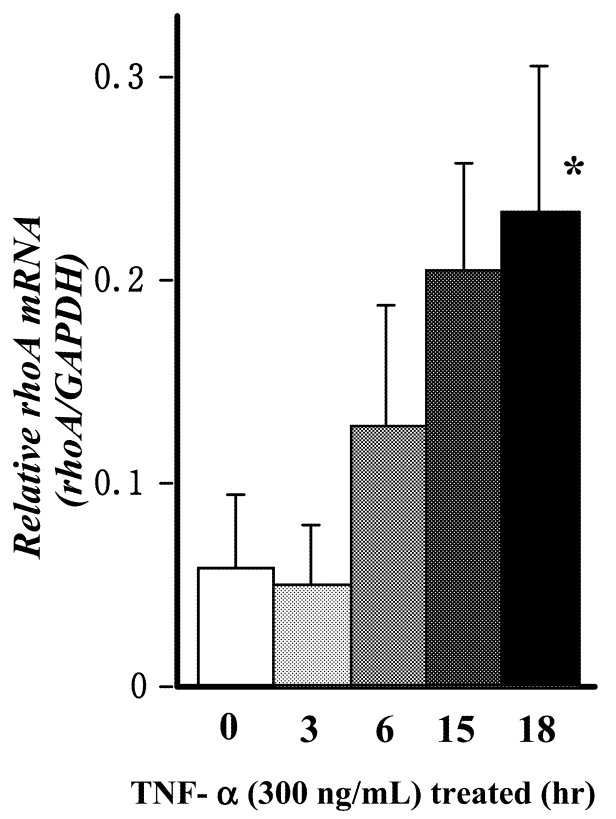

Fig. 2. The level of expression of rhoA mRNA in the TNF- $\alpha$ or non (0)-treated rat bronchial tissue. The experiments were done using the total RNA from each of 4 different animals. The expression of rhoA mRNA was increased in a time-dependent manner in the TNF- $\alpha$-treated rat bronchial tissue. The expression of rhoA mRNA was significantly increased in the $18 \mathrm{hr}$ TNF- $\alpha$-treated group ( ${ }^{*}: \mathrm{p}<0.05 \mathrm{vs} .0 \mathrm{hr}$ ).

\section{Discussion}

In the present study, treatment of rat bronchial smooth muscle preparations with TNF- $\alpha$ ( $300 \mathrm{ng} / \mathrm{ml}$ for $24 \mathrm{hr}$ ) significantly shifted the concentration-response curve to ACh upwards, but not that due to high $\mathrm{K}^{+}$, as compared to that of control preparations. The immunoblot study revealed that the expression of RhoA protein was significantly increased by TNF- $\alpha$ treatment in the rat bronchus. A semi-quantitative analysis of rhoA mRNA by RT-PCR also suggested an upregulation of RhoA in TNF- $\alpha$-treated bronchi.

Observations that TNF- $\alpha$ is released via the IgE-dependent activation of mast cells (Gordon et al., 1990) or in the sensitized human lung (Ohkawara et al., 1992) suggest that TNF- $\alpha$ contributes to the allergen-induced inflammatory response. Amrani et al. (1995) showed that exposure of human airway smooth muscle cells to TNF- $\alpha$ for $24 \mathrm{hr}$ potentiates the increase in cytosolic free calcium induced by contractile agonists such as carbachol and bradykinin. However, in the present study, TNF- $\alpha$ potentiated the ACh-, but not high $\mathrm{K}^{+}$, induced contraction of rat bronchial smooth muscle. Accordingly, TNF- $\alpha$ may increase bronchial smooth muscle contractility by augmenting receptor-mediated signaling such as that via muscarinic receptors.

We have previously demonstrated that the increased expression of RhoA protein by allergic stimulation seems to enhance the $\mathrm{Ca}^{2+}$ sensitizing signal, resulting in an augmentation of the 


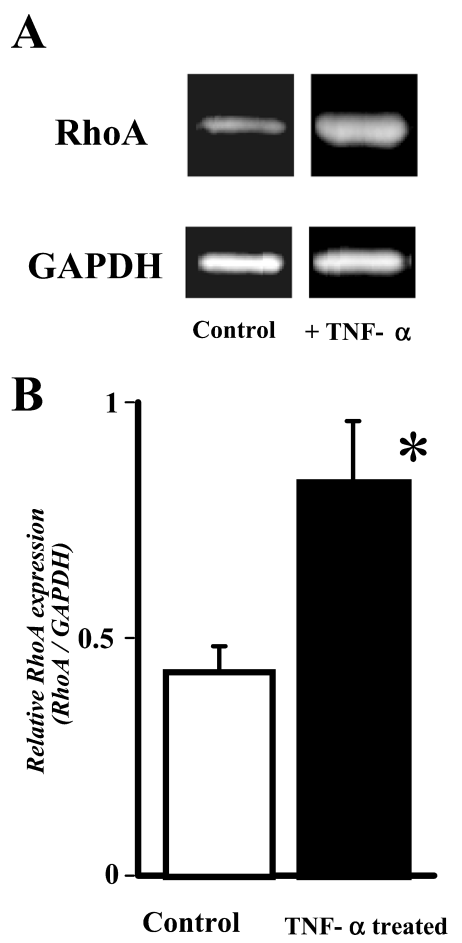

Fig. 3. (A) Typical immunoblots of RhoA (upper) and GAPDH (lower) in the TNF- $\alpha$-treated $(300 \mathrm{ng} / \mathrm{ml}$, for $24 \mathrm{hr}$ ) or vehicle (Control)-treated bronchial preparations. (B) Relative densities of RhoA to GAPDH (RhoA/GAPDH) in the TNF- $\alpha$ - or its vehicletreated bronchial preparations. Values are the mean and S.E. from 6 different animals. The expression of RhoA was significantly increased in the TNF- $\alpha$-treated bronchial preparations as compared to that in the vehicle-treated ones $\left({ }^{*}: \mathrm{p}<0.05\right.$ vs. control).

ACh-induced contractile response in antigen-challenged AHR rats (Chiba et al., 1999b). Presently, we have found that TNF- $\alpha$ treatment augments the ACh-induced bronchial smooth muscle contraction; ACh has been reported as one of the activators of RhoA in bronchial smooth muscle (Chiba et al., 2001). We have now demonstrated that the TNF- $\alpha$ augmented expression of RhoA protein occurs in rat bronchial preparations. Thus, the TNF- $\alpha$ that was produced by allergic stimulation appears to increase the agonist-induced $\mathrm{Ca}^{2+}$ sensitizing signal via an enhanced expression of RhoA protein.

It has previously been reported that a short-term exposure (for $30 \mathrm{~min}$ ) to TNF- $\alpha$ directly affects airway smooth muscle cells by augmenting muscarinic agonist-mediated contraction of both isolated guinea-pig (Pennings et al., 1998) and bovine (Nakatani et al., 2000) tracheal smooth muscle. However, although we studied a short-term exposure effect of TNF- $\alpha$ (300 ng/ $\mathrm{ml}$ for $1 \mathrm{hr}$ ), no significant difference was observed in the contraction response to ACh between treatments with or without TNF- $\alpha$ (data not shown).

The mechanisms underlying the TNF- $\alpha$-induced increase in bronchial smooth muscle contractility have not been fully elucidated. TNF- $\alpha$ initiates its pleiotropic action by binding to two receptors designated as p55 (TNFR1) and p75 (TNFR2) according to their apparent 
molecular mass. These receptors are coexpressed on the surface of mast cells (Tartaglia et al., 1992). Although both TNFR1 and TNFR2 were found to be coexpressed on airway smooth muscle cells (Amrani et al., 1996; Amrani et al., 2000a), the majority of TNF- $\alpha$ effects on airway smooth muscle are mediated by TNFR1 (Amrani et al., 2000b). TNFR1 is shown to regulate TNF- $\alpha$-induced expression of adhesion molecules (Amrani et al., 2000b). However, the receptor subtype for the TNF- $\alpha$-induced increase in bronchial smooth muscle contractility is unclear. It has been reported that TNF- $\alpha$ stimulation of TNFR1 elicited NF- $\kappa \mathrm{B}$ (nuclear factor- $\kappa \mathrm{B}$ transcription factor) activation in airway smooth muscle cell (McFarlane et al., 2001). TNF- $\alpha$ may thus stimulate RhoA expression through NF- $\mathrm{B}$ activation.

In summary, we suggest that TNF- $\alpha$ might be one of the important mediators that are involved in the pathogenesis of the augmented bronchial smooth muscle contractility in AHR and that the augmentation of the ACh-induced contractile response evoked by TNF- $\alpha$ might be mediated by upregulation of RhoA in bronchial smooth muscle.

\section{Acknowledgements}

This study was supported in part by Grant-in-Aid for Scientific Research (C) (No. 13670101) from the Ministry of Education, Culture, Sports, Science and Technology of Japan. We thank Ms. Yuri Sakai, Ms. Mayu Hirahara and Ms. Reiko Maki for their technical assistance.

\section{References}

Ackerman, V., Marini, M., Vittori, E., Bellini, A., Vassali, G. and Mattoli, S. (1994). Detection of cytokines and their cell sources in bronchial biopsy specimens from asthmatic patients. Relationship to atopic status, symptoms, and level of airway hyperresponsiveness. Chest 105: 687-696.

Amrani, Y., Lazaar, A.L., Hoffman, R., Amin, K., Ousmer, S. and Panettieri, R.A. Jr. (2000a). Activation of the p55 TNFR1 coupled to TRAF2 stimulates ICAM-1 expression by modulating a thapsigarginsensitive pathway in human tracheal smooth muscle cells. Mol. Pharmacol. 58: 237-245.

Amrani, Y., Chen, H. and Panettieri, R.A. Jr. (2000b). Activation of tumor necrosis factor receptor 1 in airway smooth muscle: a potential pathway that modulates bronchial hyper-responsiveness in asthma? Respir. Res. 1: 49-53.

Amrani, Y., Panettieri, R.A. Jr., Frossard, N. and Bronner, C. (1996). Activation of the TNF alpha-p55 receptor induces myocyte proliferation and modulates agonist-evoked calcium transients in cultured human tracheal smooth muscle cells. Am. J. Respir. Cell Mol. Biol. 15: 55-63.

Amrani, Y., Martinet, N. and Bronner, C. (1995). Potentiation by tumour necrosis factor-alpha of calcium signals induced by bradykinin and carbachol in human tracheal smooth muscle cells. $B r . J$. Pharmacol. 114: 4-5.

Bousquet J. (2000). Relating inflammatory changes in asthma to clinical status. Respir. Med. 94: 32-33

Bradding, P., Roberts, J.A., Britten, K.M., Montefort, S., Djukanovic, R., Mueller, R., Heusser, C.H., Howarth, P.H. and Holgate, S.T. (1994). Interleukin-4, -5 and -6 and tumor necrosis factor-alpha in normal and asthmatic airways: evidence for the human mast cell as a source of these cytokines. Am. J. Pespir. Cell Mol. Biol. 10: 471-480.

Broide, D.H., Lotz, M., Cuomo, A.J., Coburn, D.A., Federman, E.C. and Wasserman, S.I. (1992). Cytokines in symptomatic asthma airways. J. Allergy Clin. Immunol. 89: 958-967.

Chiba, Y., Sakai, H. and Misawa, M. (2001). Augmented acetylcholine-induced translocation of RhoA in 
bronchial smooth muscle from antigen-induced airway hyperresponsive rats. Br. J. Pharmacol. 427: 77-82.

Chiba, Y., Sakai, H., Suenaga, H., Kamata, K. and Misawa, M. (1999a). Enhanced Ca ${ }^{2+}$ sensitization of the bronchial smooth muscle contraction in antigen-induced airway hyperresponsive rats. Res. Commun. Mol. Pathol. Pharmacol. 106: 77-85.

Chiba, Y., Takada, Y., Miyamoto, S., Mitsui-Saito, M., Karaki, H. and Misawa, M. (1999b). Augmented acetylcholine-induced, Rho-mediated $\mathrm{Ca}^{2+}$ sensitization of bronchial smooth muscle contraction in antigen-induced airway hyperresponsive rats. Br. J. Pharmacol. 127: 597-600.

Chiba, Y. and Misawa, M. (1995). Characteristics of muscarinic cholinoceptors in airways of antigeninduced airway hyperresponsive rats. Comp. Biochem. Physiol. C Pharmacol. Toxicol. Endocrinol. 111: 351-357.

Chiba, Y. and Misawa, M. (1993). Strain differences in change in airway responsiveness after repeated antigenic challenge in three strains of rats. Gen. Pharmacol. 24: 1265-1272.

Costa, J.J., Matossian, K., Resnick, M.B., Beil, W.J., Wong, D.T., Gordon, J.R., Dvorak, A.M., Weller, P.F. and Galli, S.J. (1993). Human eosinophils con express the cytokine tumor necrosis factor-alpha and macrophage inflammatory protein-1 alpha. J. Clin. Invest. 91: 2673-2684.

Devalia, J.L., Campbell, A.M., Sapsford, R.J., Rusznak, C., Quint, D., Godard, P., Bousquet, J. and Davies, R.J. (1993). Effect of nitrogen dioxide on synthesis of inflammatory cytokines expressed by human bronchial epithelial cells in vitro. Am. J. Respir. Cell Mol. Biol. 9: 271-278.

Escott, K.J., Belvisi, M.G., Birrell, M.A., Webber, S.E., Foster, M.L. and Sargent, C.A. (2000). Effect of the p38 kinase inhibitor, SB 203580, on allergic airway inflammation in the rat. Br. J. Pharmacol. 131: 173-176.

Finotto, S., Ohno, I., Marshall, J.S., Gauldie, J., Denburg, J.A., Dolovich, J., Clark, D.A. and Jordana, M. (1994). TNF-alpha production by eosinophols in upper airways inflammation (nasal polyposis). Immunology 153: 2278-2289.

Gordon, J.R. and Galli, S.J. (1990). Mast cells as a source of both preformed and immunologically inducible TNF- $\alpha$ /cachectin. Nature (Lond.) 346: 274-276.

Gosset, P., Tsicopoulos, A., Wallaert, B., Joseph, M., Capron, A. and Tonnel, A.B. (1992). Tumor necrosis factor alpha and interleukin-6 production by human mononulear phagocyte from allergic asthmatics after IgE-dependent stimulation. Am. Rev. Respir. Dis. 146: 768-774.

Kips, J.C., Tavernier, J. and Pauwels, R.A. (1992). Tumor necrosis factor causes bronchial hyperresponsiveness in rats. Am. Rev. Respir. Dis. 145: 332-336.

Lotvall, J., Inman, M. and O’byrne, P. (1998). Measurement of airway hyperresponsiveness: new considerations. Thorax 53: 419-424.

Lucacs, N.W., Strieter, R.M., Chensue, S.W., Widmer, M. and Kunkel, S.L. (1995). TNF-alpha mediates recruitment of neutrophils and eosinophils during airway inflammation. J. Immunol. 154: 54115417.

McFarlane, S.M., Jupp, O.J., Cobban, H.J., Hunter, I., Anderson, H.M., Vandenabeele, P., Nixon, F.F. and MacEwan, D.J. (2001). Stimulation of stress-activated but not mitogen-activated protein kinases by tumour necrosis factor receptor subtypes in airway smooth muscle. Biochem. Pharmacol. 61: 749-759.

Mullis, K., Faloona, F., Scharf, S., Saiki, R., Horn, G. and Erlich, H. (1989). Specific enzymatic amplification of DNA in vitro: the polymerase chain reaction. Cold spring Harb. Symp. Quant. Biol. 51: 263-273.

Nakatani, Y., Nishimura, Y., Nishimura, T., Maeda, H. and Yokoyama, M. (2000). Tumor necrosis factor$\alpha$ augments contraction and cytosolic $\mathrm{Ca}^{2+}$ sensitivity through phospholipase A2 in bovine tracheal smooth muscle. Eur. J. Pharmacol. 392: 175-182.

Ohkawara, Y., Yamauchi, K., Tanno, Y., Tamura, G., Ohtani, H., Nagura, H., Ohkuda, K. and Takishima, T. (1992). Human lung mast cells and pulmonary macrophages produce tumor necrosis factor- 
alpha in sensitized lung tissue after IgE receptor triggering. Am. J. Respir. Cell Mol. Biol. 7: 385-392.

Otto, B., Steusloff, A., Just, I., Aktories, K. and Pfizer, G. (1996). Role of Rho proteins in carbacholinduced contractions in intact and permeabilized guinea-pig intestinal smooth muscle. J. Physiol. 496: 317-329.

Pennings, H.J., Kramer, K., Bast, A., Buurman, W.A. and Wouters, E.F.M. (1998). Tumour necrosis factor- $\alpha$ induces hyperreactivity in tracheal smooth muscle of the guinea-pig in vitro. Eur. Respir. J. 12: 45-49.

Renzetti, L.M., Paciorek, P.M., Tannu, S.A., Rinaldi, N.C., Tocker, J.E., Wasserman, M.A. and Gater, P.R. (1996). Pharmacological evidence for tumor necrosis factor as a mediator of allergic inflammation in the airways. J. Pharmacol. Exp. Ther. 278: 847-853.

Shah, A., Church, M.K. and Holgate, S.T. (1995). Tumour necrosis factor alpha: a potential mediator of asthma. Clin. Exp. Allergy 25: 1038-1044.

Sukkar, M.B., Hughes, J.M., Armour, C.L. and Johnson, P.R.A. (2001). Tumour necrosis factor- $\alpha$ potentiates contraction of human bronchus in vitro. Respirology 6: 199-203.

Taki, F., Kondoh, Y., Matsumoto, K., Takagi, K., Satake, T., Taniguchi, H. and Matsuzaki, M. (1991). Tumor necrosis factor in sputa of patients with bronchial asthma on exacerbation. Arerugi 40: 643-646. (in Japanese).

Tartaglia, L.A., Pennica, D. and Goeddel, D.V. (1992). Two TNF-receptors. Immunol. Today 13: 151-153.

Thomas, P.S., Yates, D.H. and Barnes, P.J. (1995). Tumor necrosis factor-alpha increases airway responsiveness and sputum neutrophilia in normal human subjects. Am. J. Respir. Crit. Care Med. 152: 76-80.

Watson, M.L., Smith, D., Bourne, A.D., Thompson, R.C. and Westwick, J. (1993). Cytokines contribute to airway dysfunction in antigen-challenged guinea pig: inhibition of airway hyperreactivity, pulmonary eosinophil accumulation, and tumor necrosis factor generation by pretreatment with an interleukin-1 receptor antagonist. Am. J. Respir. Cell Mol. Biol. 8: 365-369.

Yoshimura, S-I., Sakai, H., Nakazawa, S., Nozawa, Y., Shinoda, J., Sakai, N. and Yamada, H. (1997). Differential expression of Rho family GTP-binding proteins and protein kinase C isozymes during C6 glial cell differentiations. Mol. Brain Res. 45: 90-98.

(Received December 3, 2003; Accepted January 16, 2004) 